\title{
Validitas dan Reliabilitas Instrumen Determinan Kepatuhan Minum Obat pada Pasien Lupus Eritematosus Sistemik
}

\author{
Shiane Hanako Sheba \\ Politeknik Al Islam Bandung \\ shianehanako2014@gmail.com
}

\begin{abstract}
ABSTRAK
Lupus Eritematosus Sistemik (LES) adalah penyakit autoimun kronis yang belum diketahui penyebabnya sehingga penyandangnya harus mengonsumsi obat jangka panjang untuk mengendalikan penyakitnya. Keadaan ini menimbulkan dampak fisik dan ekonomi karena efek samping serius dan biaya tinggi yang sering memengaruhi kepatuhan minum obat. Determinan kepatuhan berbeda di setiap lokasi karena perbedaan sosial, politik dan budaya. Penelitian bertujuan mendapatkan instrumen determinan kepatuhan minum obat pasien LES yang valid dan reliabel.

Telah dilakukan penelitian kuantitatif terhadap 30 pasien LES di klinik Reumatologi RSUP Dr. Hasan Sadikin Bandung dengan teknik consecutive sampling. Analisis data menggunakan pemodelan Rasch.

Uji validitas 103 butir pernyataan menunjukkan: 83 butir tergolong fit statistic; seluruh butir terbukti unidimensi dan tidak ditemukan konflik antar butir (dimensionality); 4 pilihan jawaban mampu dipahami perbedaannya oleh responden (rating scale). Uji reliabilitas menunjukkan: reliabilitas dan separasi strata butir sangat baik; reliabilitas dan separasi strata responden baik; Alpha Cronbach sangat baik $(0,88)$.

Penelitian ini menghasilkan instrumen determinan kepatuhan minum obat pada pasien LES yang valid dan reliabel, mewakili 51 konstruk dan 13 kategori: karakteristik individu, daya ingat, pengetahuan, eksperimen, manajemen konsumsi, karakteristik penyakit, karakteristik obat, biaya, kebijakan rumah sakit, akses ke rumah sakit, enabler agent, karakteristik tenaga kesehatan dan dukungan eksternal.
\end{abstract}

Kata Kunci: determinan kepatuhan, instrumen reliabel, Instrumen valid, Lupus.

\begin{abstract}
Systemic Lupus Erythematosus (SLE) is a chronic autoimmune disease with unknown etiology so the patient needs long-term treatment to control the illness. It could impact physical and economic burden due to serious side effects and high cost treatment that affect drug adherence. The determinants of drug adherence vary by location due to social, political and cultural differences. The aim of this study is to obtain a valid and reliable insrument of drug adherence determinant for SLE patients.
\end{abstract}


Quantitative research was conducted on 30 SLE patients at Rheumatology clinic of Dr. Hasan Sadikin Hospital Bandung with consecutive sampling technique. Data was analyzed by Rasch model.

The validity of 103 instrument item shows: 83 items are fit statistic; all items are unidimensional and no inter-items conflict; differences of 4 points scale are understood by the respondent. Reliability shows: items reliability and strata separation are excellent; responden reliability and strata separation are good; Cronbach's Alpha is excellent (0.88).

The result of this study is a valid and reliable instrumen of drug adherence determinants for SLE patient, representing 51 constructs and 13 categories: individual characteristics, memory, knowledge, experimentation, consumption management, disease characteristics, drug characteristics, costs, hospital policies, access to hospitals, enabler agents, characteristics of health proffesional and social support.

Keywords: adherence determinant, Lupus, reliable instrument, valid instrument.

\section{PENDAHULUAN}

Lupus Eritematosus Sistemik (LES) atau yang dikenal sebagai penyakit lupus adalah penyakit peradangan kronis akibat terganggunya sistem imun tubuh. ${ }^{1}$ LES belum diketahui penyebabnya sehingga belum dapat disembuhkan, pengobatan hanya bertujuan untuk mengendalikan penyakit dan mencegah kematian. Orang dengan lupus (odapus) harus mengonsumsi berbagai jenis obat dalam waktu lama bahkan seumur hidupnya, yang sering menimbulkan efek samping serius bahkan memperburuk kondisi odapus. ${ }^{2}$ Keadaan tersebut menyebabkan tingginya angka ketidakpatuhan minum obat pada pasien LES, yang dapat dilihat di beberapa negara berikut: Selandia Baru (46\%), Brasil (20\%), dan Mesir (38\%).

Dipihak lain, ketidakpatuhan minum obat pada penyakit LES dapat menimbulkan dampak negatif berupa outcome yang buruk dan biaya tinggi akibat peningkatan kunjungan ke unit gawat darurat dan rawat inap. ${ }^{3,6,7}$ Hal tersebut menambah beban fisik, psikis juga ekonomi yang harus ditanggung oleh odapus dan keluarganya, sehingga LES digolongkan sebagai penyakit katastropik. ${ }^{8}$

Mengingat dampak yang cukup penting, maka tindakan intervensi dan pencegahan untuk mengatasi ketidakpatuhan minum obat pada lupus perlu dilakukan, salah satunya dengan mengetahui determinan kepatuhan tersebut.

Determinan ketidakpatuhan minum obat sangat bervariasi di berbagai negara karena perbedaan alat ukur dan lokasi penelitian. Lokasi penelitian sebagai salah satu faktor penting dalam determinan kepatuhan terkait perbedaan budaya, sistem kesehatan, lingkungan sosial, ekonomi maupun politik di masing-masing negara. ${ }^{9}$ Adanya variasi determinan kepatuhan yang cukup besar menyebabkan perlu diketahuinya determinan kepatuhan minum obat pada pasien LES yang dapat menjadi alat ukur sesuai kondisi di Indonesia.

Belum ada penelitian yang menghasilkan kuesioner determinan kepatuhan minum obat pada pasien lupus di Indonesia. Penelitian determinan kepatuhan di negara lain telah dilakukan di Amerika Serikat berupa penelitian kualitatif yang tidak menghasilkan kuesioner. ${ }^{10}$ Salah satu 
penelitian kuantitatif tentang determinan kepatuhan minum obat lupus di Amerika Serikat pada tahun 2012 menggunakan kuesioner Adult AIDS Clinical Trials Group (AACTG). ${ }^{11}$

Eksplorasi kualitatif determinan kepatuhan minum obat pada pasien LES di Indonesia dengan menggunakan panduan teori perilaku Lawrence Green menghasilkan 57 konstruk dan 14 kategori determinan kepatuhan yaitu: karakteristik individu, daya ingat, pengetahuan, eksperimen, dan manajemen konsumsi (predisposing); karakteristik penyakit, karakteristik obat, biaya, kebijakan rumah sakit, akses ke rumah sakit, terapi alternatif dan enabler agent (enabling); karakteristik tenaga kesehatan dan dukungan eksternal dari berbagai pihak (reinforcing). Konsep-konsep dan konstruk yang ditemukan membangun konstruk lokal Jawa Barat berlatar belakang karakteristik masyarakat sunda dan bersifat kontekstual terhadap penyakit LES. ${ }^{12}$

Penelitian ini bertujuan untuk membangun instrumen determinan kepatuhan minum obat pada pasien LES di Indonesia berdasarkan konstruk yang diperoleh dari penelitian kualitatif di atas. Selanjutnya uji validitas serta reliabilitas dilakukan agar dihasilkan instrumen yang berkualitas dan dapat mengukur konstruk secara konsisten dan akurat. Instrumen yang dihasilkan diharapkan dapat digunakan untuk memberikan gambaran mengenai penatalaksanaan LES di Indonesia, pada akhirnya dapat berdampak terhadap peningkatan kualitas hidup dan penurunan angka kematian odapus.

\section{METODE PENELITIAN}

Definisi operasional instrumen dibangun dari ekstraksi 57 konstruk dan konsep hasil eksplorasi kualitatif sebelumnya yang menghasilkan 107 butir pernyataan dengan pilihan jawaban menggunakan skala Likert berupa 4 pilihan jawaban yaitu sangat setuju hingga sangat tidak setuju. Validitas internal dilakukan terhadap satu orang pendapat ahli dan validitas respon kuesioner terhadap satu orang calon responden. Berdasarkan hasil validitas internal tersebut dilakukan modifikasi kuesioner berupa perbaikan kalimat dan pengurangan butir pernyataan dengan hasil akhir berupa 103 butir pernyataan yang seluruhnya dianggap telah mewakili konstruk determinan kepatuhan minum obat pada pasien LES.

Penelitian dilaksanakan di klinik reumatologi RSUP Dr. Hasan Sadikin pada bulan Juli hingga September 2016 dengan persetujuan Komite Etik Penelitian Kesehatan Fakultas Kedokteran Universitas Padjadjaran melalui Ethical Approval Nomor 412/UN6.C1.3.2/KEPK/PN/2016. Subjek penelitian adalah 30 orang pasien rawat jalan dengan kriteria inklusi: pasien LES terdiagnosis lupus minimal selama 1 tahun dengan menggunakan kriteria Systemic Lupus International Collaborating Clinics (SLICC), sedang mengonsumsi obat lupus, dan bersedia mengikuti penelitian. Kriteria eksklusi adalah: pasien sedang hamil dan menyusui, menderita gangguan penglihatan berat, dan menderita gangguan pendengaran berat. Jumlah subjek penelitian ditetapkan berdasarkan tabel Linacre untuk mengukur validitas dan reliabilitas instrumen menggunakan Rasch model pada kisaran \pm 1 logit dengan tingkat kepercayaan $95 \% .^{13}$ Cara pengambilan sampel dengan teknik consecutive sampling, yaitu berasal dari subjek yang datang berturut-turut ke klinik lupus yang memenuhi kriteria inklusi dan eksklusi hingga mencapai ukuran sampel yang dibutuhkan selama periode penelitian berlangsung. Masingmasing subjek mengisi langsung lembar isian dalam kuesioner didampingi peneliti dengan waktu pengisian kuesioner tiap subjek lebih kurang 40 menit.

Analisis uji validitas dan reliabilitas instrumen menggunakan pemodelan Rasch dengan perangkat lunak Winsteps versi 3.73. Uji validitas instrumen dilakukan melalui analisis terhadap nilai-nilai berikut: tingkat kesesuaian butir kuesioner (item fit) yang mengandung makna bahwa 
butir pernyataan berfungsi normal melakukan pengukuran yaitu tidak terjadi miskonsepsi responden; nilai dimensionality untuk menjamin bahwa instrumen berfungsi sebagai alat ukur yang uni-dimensi atau hanya mengukur apa yang seharusnya diukur saja; serta analisis rating scale untuk menentukan bahwa responden memahami pilihan jawaban (rating) yang tersedia. ${ }^{14}$

Uji reliabilitas dilakukan sesuai pemodelan Rasch yaitu analisis terhadap: reliabilitas butir (item reliability) dan reliabilitas responden (person reliability) untuk mengukur keandalan instrumen dalam perbedaan tingkat kesulitan butir dan kemampuan responden; nilai alpha Cronbach untuk mengukur interaksi antara responden dan butir pernyataan secara keseluruhan; serta separasi butir dan responden untuk mengukur rentang tingkat kesulitan butir-butir pernyataan dan rentang tingkat kemampuan responden. Reliabilitas instrumen dikatakan tinggi jika taraf kesukaran butir dan sampel penelitian memiliki jangkauan luas. ${ }^{14}$

\section{HASIL DAN PEMBAHASAN}

Hasil penelitian menunjukkan karakteristik subjek sebagai berikut:

Tabel 1. Karakteristik Subjek

\begin{tabular}{|c|c|c|}
\hline Karakteristik & $\begin{array}{l}\text { Frekuensi } \\
(\mathbf{n}=\mathbf{3 0})\end{array}$ & Persentase (\%) \\
\hline \multicolumn{3}{|l|}{ Jenis Kelamin } \\
\hline Laki-laki & 3 & 10 \\
\hline Perempuan & 27 & 90 \\
\hline \multicolumn{3}{|l|}{ Status Pernikahan } \\
\hline Menikah & 7 & 23 \\
\hline Belum Menikah & 21 & 70 \\
\hline Pernah menikah & 2 & 7 \\
\hline \multicolumn{3}{|l|}{ Asal Domisili } \\
\hline Kota Bandung & 17 & 56 \\
\hline Luar Kota Bandung (Jawa Barat) & 13 & 44 \\
\hline \multicolumn{3}{|l|}{ Usia } \\
\hline $21-30$ & 16 & 53 \\
\hline $31-40$ & 6 & 20 \\
\hline $41-50$ & 5 & 17 \\
\hline$>50$ & 3 & 10 \\
\hline \multicolumn{3}{|l|}{ Pendidikan } \\
\hline $\mathrm{SD}$ & 5 & 17 \\
\hline SMP & 3 & 10 \\
\hline SMA & 15 & 50 \\
\hline Perguruan tinggi & 7 & 23 \\
\hline \multicolumn{3}{|l|}{ Pekerjaan } \\
\hline Pelajar & 1 & 3 \\
\hline Pegawai swasta & 3 & 10 \\
\hline
\end{tabular}




\begin{tabular}{lll} 
Wiraswasta & 3 & 10 \\
Ibu rumah tangga & 18 & 60 \\
Lain-lain & 5 & 17 \\
\hline
\end{tabular}

Karakteristik subjek berupa jenis kelamin dan usia memperlihatkan 27 subjek (90\%) berjenis kelamin perempuan berusia produktif antara 21-50 tahun, hal ini sesuai dengan pernyataan Wallace dalam Dubois Lupus Erythematosus yang menyatakan bahwa $90 \%$ penyandang lupus adalah wanita aktif usia produktif. ${ }^{15}$

Hasil yang diperoleh dari tabel item fit pemodelan Rasch berdasarkan urutan nomor butir kuesioner adalah sebagai berikut:

Tabel 2. Tabel Item Fit

\begin{tabular}{|c|c|c|c|c|c|}
\hline \multirow{2}{*}{ No } & \multirow{2}{*}{ Konstruk } & \multicolumn{3}{|c|}{ Fit Statistic } & \multirow{2}{*}{ Hasil } \\
\hline & & MNSQ & ZSTD & Pt. Mea Corr & \\
\hline \multicolumn{6}{|c|}{ Karakteristik Individu } \\
\hline 1 & Optimisme & 0.86 & -0.6 & 0.82 & fit \\
\hline 2 & Optimisme & 1.17 & 0.8 & 1.14 & fit \\
\hline 3 & Bersyukur & 0.7 & -1.2 & 0.47 & fit \\
\hline 4 & Bersyukur & 0.83 & -0.6 & 0.83 & fit \\
\hline 5 & Mandiri & 1.31 & 1.1 & 0.01 & fit \\
\hline 6 & Mandiri & 1.02 & 0.2 & 1.01 & fit \\
\hline 7 & Bermanfaat & 0.9 & -0.4 & 0.89 & fit \\
\hline 8 & Bermanfaat & 0.91 & -0.4 & 0.91 & fit \\
\hline 9 & Keyakinan agama & 1.67 & 1.2 & -0.4 & tidak fit \\
\hline 10 & Keyakinan agama & 0.84 & -0.5 & 0.37 & fit \\
\hline 11 & Supel & 0.64 & -1.8 & 0.65 & fit \\
\hline 12 & Supel & 0.86 & -0.5 & 0.88 & fit \\
\hline 13 & Kejujuran & 0.64 & -1.5 & 0.24 & fit \\
\hline 13 & Kejujuran & 0.71 & -1.4 & 0.72 & fit \\
\hline 15 & Tanggung jawab & 0.61 & -2 & 0.6 & fit \\
\hline 16 & Tanggung jawab & 0.91 & -0.3 & 0.91 & fit \\
\hline 17 & Keingintahuan & 0.7 & -1.4 & 0.7 & fit \\
\hline 18 & Keingintahuan & 0.78 & -1 & 0.78 & fit \\
\hline 19 & Penerimaan & 0.58 & -1.8 & 0.59 & fit \\
\hline 20 & Penerimaan & 1.7 & 2.1 & 0.3 & tidak fit \\
\hline 21 & Pemaknaan penyakit & 1.91 & 2.9 & -0.23 & tidak fit \\
\hline 22 & Pemaknaan penyakit & 0.93 & -0.2 & 0.94 & fit \\
\hline 23 & Self compare & 0.78 & -1 & 0.74 & fit \\
\hline 24 & Self compare & 0.63 & -1.6 & 0.65 & fit \\
\hline 25 & Self esteem & 1.05 & 0.3 & -0.11 & fit \\
\hline 26 & Self esteem & 1.07 & 0.4 & -0.13 & fit \\
\hline
\end{tabular}




$\begin{array}{ll}27 & \text { Relieved } \\ 28 & \text { Relieved } \\ 29 & \text { Percaya } \\ 30 & \text { Percaya } \\ 31 & \text { Kontrol diri } \\ 32 & \text { Kontrol diri } \\ 33 & \text { Konsistensi } \\ 34 & \text { Konsistensi } \\ 35 & \text { Prioritizing } \\ 36 & \text { Prioritizing }\end{array}$

\section{Daya ingat}

37 Daya ingat

38 Daya ingat

\section{Pengetahuan}

39 Pengetahuan penyakit

40 Pengetahuan penyakit

\section{Eksperimen}

41 Eksperimen

42 Eksperimen

Manajemen konsumsi

$\begin{array}{ll}43 & \text { Reminder } \\ 44 & \text { Persediaan obat } \\ 45 & \text { Persediaan }\end{array}$

45 Persediaan obat

\section{Karakteristik penyakit}

46 Gejala penyakit

47 Gejala penyakit

48 Aktifitas penyakit

49 Aktifitas penyakit

50 Penyakit lain

51 Penyakit lain

52 Konsekuensi

53 Konsekuensi

\section{Karakteristik Obat}

54 khasiat terapi

55 khasiat terapi

56 Efek samping

57 Efek samping

58 Jumlah obat

59 Jumlah obat

60 Sifat fisik obat

61 Sifat fisik obat

62 Tindakan terapi

$\begin{array}{lr}0.73 & -1 \\ 0.57 & -2.1 \\ 0.43 & -2.9 \\ 0.45 & -2.7 \\ 0.83 & -0.6 \\ 0.31 & -3.6 \\ 0.54 & -1.9 \\ 0.85 & -0.5 \\ 0.51 & -2.1 \\ 0.93 & -0.2\end{array}$

0.49

$-2.2$

0.54

$-2.1$

$\begin{array}{ll}0.89 & -0.3 \\ 0.81 & -0.7\end{array}$

$0.81 \quad-0.7$

$1.14 \quad 0.6$

1.17

0.7

$\begin{array}{ll}1.38 & 1.5\end{array}$

$1.06 \quad 0.3$

$1.32 \quad 1.1$

1.31

1.1

1.75

2.02

$0.7-1.1$

1.16

0.99

0.76

0.53

2.3

3.1

0.8

0.1

$-1$

$-2.4$

$\begin{array}{ll}0.43 & -2.9\end{array}$

$0.45 \quad-2.8$

$1.4 \quad 1.7$

$1.04 \quad 0.3$

$1.16 \quad 0.8$

1.26

1.52

1.2

1.45

2.2

2

1.36

1.5

$-30$

$\begin{array}{lc}0.74 & \text { fit } \\ 0.57 & \text { fit } \\ 0.44 & \text { tidak fit } \\ 0.46 & \text { tidak fit } \\ 0.42 & \text { fit } \\ 0.67 & \text { fit } \\ 0.36 & \text { fit } \\ 0.32 & \text { fit } \\ 0.51 & \text { fit } \\ 0.14 & \text { fit }\end{array}$

0.52 tidak fit

0.56 fit

$\begin{aligned} 0.3 & \text { fit } \\ 0.81 & \text { fit }\end{aligned}$

$0.21 \quad$ fit

0.37 fit

$\begin{array}{ll}0.21 & \text { fit } \\ 1.16 & \text { fit } \\ 0.27 & \text { fit }\end{array}$

0.32 fit

0.04 tidak fit

2.01 tidak fit

0.57 fit

0.09 fit

-0.02 fit

$0.77 \quad$ fit

0.53 fit

0.45 tidak fit

0.46 tidak fit

-0.02 fit

-0.13 fit

-0.19 fit

-0.16 fit

-0.19 tidak fit

-0.05 fit

$-0.37 \quad$ fit 


$\begin{array}{ll}63 & \text { Tindakan terapi } \\ 64 & \text { Dosis } \\ 65 & \text { Dosis } \\ 66 & \text { Kualitas obat } \\ 67 & \text { Kualitas obat }\end{array}$

\section{Biaya}

$\begin{array}{ll}68 & \text { Biaya } \\ 69 & \text { Biaya } \\ 70 & \text { Bantuan biaya } \\ 71 & \text { Kendala ekonomi } \\ 72 & \text { Kendala ekonomi } \\ 73 & \text { Jaminan biaya } \\ 74 & \text { Jaminan biaya }\end{array}$

Kebijakan RS

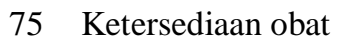

76 Ketersediaan obat

77 Sarana prasarana

78 Sarana prasarana

79 Sistem rujukan

80 Sistem rujukan

81 Kompetensi dokter

82 Kompetensi dokter

$\begin{array}{rr}1.26 & 1.2 \\ 1.66 & 2.6 \\ 1.13 & 0.6 \\ 0.91 & -0.4 \\ 0.7 & -1.3\end{array}$

2.01

2.9

1.31

1.54

1.82

1.69

0.63

0.51

$\begin{array}{rr}1.01 & 0.1 \\ 1.04 & 0.2 \\ 1.2 & 0.9 \\ 1.28 & 1.2 \\ 0.93 & -0.1 \\ 0.94 & -0.1 \\ 0.9 & -0.3 \\ 0.84 & -0.5\end{array}$

0.46

$-2.4$

1.09

0.4

2.09

3.7

\section{Terapi Alternatif}

86 Terapi alternatif

87 Terapi alternatif

\section{Enabler Agent}

88 Active screening

89 Dispensasi

90 Dispensasi

\section{Karakteristik Nakes}

91 Informasi medis

92 Informasi medis

93 Kepedulian

94 Kepedulian

95 Empati

96 Empati

Dukungan Eksternal

97 Dukungan keluarga

$\begin{array}{ll}1.95 & 2.9 \\ 2.05 & 3.3\end{array}$

$1.13 \quad 0.6$

$0.89-0.3$

$0.83-0.6$

$\begin{array}{ll}0.58 & -2.1 \\ 0.66 & -1.4 \\ 0.93 & -0.2 \\ 0.59 & -1.8 \\ 0.61 & -1.9 \\ 0.51 & -2.5\end{array}$

0.58

$-2.2$

$-31$

$\begin{array}{rc}-0.35 & \text { fit } \\ -0.13 & \text { tidak fit } \\ -0.21 & \text { fit } \\ 0.89 & \text { fit } \\ 0.7 & \text { fit }\end{array}$

-0.12 tidak fit

0.31 fit

0.14 tidak fit

-0.12 tidak fit

-0.02 tidak fit

0.63 fit

0.52 fit

$\begin{array}{ll}0.24 & \text { fit } \\ 0.24 & \text { fit } \\ 0.38 & \text { fit } \\ 0.17 & \text { fit } \\ 0.49 & \text { fit } \\ 0.35 & \text { fit } \\ 0.33 & \text { fit } \\ 0.57 & \text { fit }\end{array}$

0.52 tidak fit

0.26 fit

-0.14 tidak fit

0.15 tidak fit

0.16 tidak fit

$\begin{array}{ll}1.12 & \text { fit } \\ 0.61 & \text { fit } \\ 0.69 & \text { fit }\end{array}$

$0.59 \quad$ fit

0.68 fit

0.95 fit

$0.6 \quad$ fit

0.65 fit

0.52 fit 


\begin{tabular}{rlrrrr}
98 & Dukungan orangtua & 0.69 & -1.5 & 0.66 & fit \\
99 & Dukungan pasangan & 1.15 & 0.7 & 1.12 & fit \\
100 & Dukungan teman & 0.62 & -1.8 & 0.62 & fit \\
101 & Lingkungan & 0.53 & -2.1 & 0.55 & fit \\
102 & Dukungan lembaga & 1.49 & 1.8 & 0.21 & fit \\
103 & Kerelawanan & 1.65 & 2 & 0.46 & fit \\
\hline
\end{tabular}

Butir instrumen valid menurut Boone jika memenuhi 2 dari 3 kriteria berikut, yaitu: nilai Outfit Mean Square (MNSQ) 0,5 < MNSQ < 1,5; nilai Outfit Z-Standard (ZSTD) -2,0 < ZSTD < +2,0; atau nilai Point Measure Correlation (Pt Mea Corr) 0,4 < Pt Mea Corr $<0,85 .{ }^{14}$

Pada tabel 2 di atas terdapat 21 butir pernyataan yang tidak memenuhi syarat fit statistik $M N S Q$ yang memperlihatkan nilai Outfit MNSQ lebih dari (+1,5 logit) atau kurang $(+0,5$ logit) yang dianggap dapat membingungkan responden. Khusus untuk butir 48, 68, 85, dan 87 yang memiliki nilai Outfit MNSQ (+2,0 logit) dapat dianggap kurang produktif sehingga dapat menurunkan kualitas pengukuran.

Nilai Outfit ZSTD pada tabel 2 memperlihatkan 23 butir pernyataan memiliki logit Outfit ZSTD lebih dari (+2.0 logit) atau kurang dari (-2,0 logit) yang berarti bahwa kesesuaian pernyataan dengan responden tidak dapat diprediksi, terutama pada butir pernyataan 48, 85, dan 87 yang memiliki outfit ZSTD lebih dari (+3,0 logit) menggambarkan ketidaksesuaian butir pernyataan dengan responden terjadi secara mutlak. namun dapat dikurangi dengan memperbanyak jumlah sampel.

Pada tabel 2 terdapat 58 butir pernyataan memiliki nilai Pt Mea Corr kurang dari $(+0,4$ logit) atau lebih dari (+0,85 logit), hal ini menunjukkan bahwa pernyataan-pernyataan tersebut kurang fokus dan sulit dijawab oleh responden. Klasifikasi lain membedakan nilai outfit Pt Mea Corr negatif atau positif; pada tabel 2 terdapat 18 butir pernyataan yang memiliki nilai Pt Mea Corr < (0 logit) hal ini menunjukkan bahwa pernyataan yang dibangun tidak dapat mengukur konstruk yang seharusnya diukur.

Berdasarkan uraian di atas, maka dari seluruh butir pernyataan kuesioner kepatuhan minum obat pada pasien lupus terdapat 20 butir pernyataan yang misfit item atau tidak memenuhi minimal 2 dari 3 kriteria yang ditetapkan yaitu butir pernyataan 9, 20, 21, 29, 30, 37, 47, 48, 54, 55, 60, 64, $69,70,71,72,83,85,86$, dan $87 .{ }^{14}$ Ke-20 butir pernyataan tersebut mewakili 16 konstruk dalam 7 kategori, yaitu: keyakinan agama, penerimaan, pemaknaan, percaya (kategori karaktersitik individu); daya ingat (kategori daya ingat); gejala penyakit, aktifitas penyakit (kategori karakteristik penyakit); khasiat terapi, sifat fisik obat, dosis (kategori karakteristik obat); biaya, bantuan biaya, kendala ekonomi (kategori biaya); transportasi, jarak (kategori akses fasyankes); terapi alternatif (kategori terapi alternatif).

Terdapat 5 konstruk yang harus diperbaiki karena seluruh butir pernyataan (10 butir pernyataan) dalam konstruk tersebut termasuk kategori misfit item sehingga konstruk tidak dapat diukur dalam instrumen determinan kepatuhan ini, yaitu: percaya, khasiat terapi, bantuan biaya, kendala ekonomi, dan terapi alternatif. 
Tabel 3. Item Dimensionality

\begin{tabular}{cc}
\hline \multicolumn{1}{c}{ Kriteria } & Nilai \\
\hline Variance in data explained by measure & $44,2 \%$ \\
Unexplained variance in contrast 1-5 & \\
unexplained variance in 1st contrast & $14,6 \%$ \\
unexplained variance in 2nd contrast & $11,0 \%$ \\
unexplained variance in 3rd contrast & $10,2 \%$ \\
unexplained variance in 4th contrast & $8,1 \%$ \\
unexplained variance in 5th contrast & $5,8 \%$ \\
\hline
\end{tabular}

Uji validitas lain dalam pemodelan Rasch adalah Dimensionality, yaitu ditentukan dengan melihat nilai variance explained in measure dan nilai unexplained variance in contrast 1-5. Kriteria nilai variance in data explained by measure adalah buruk $(<20 \%)$, cukup $(20-40 \%)$, baik (40-60\%), sangat baik (>60); sedangkan kriteria penilaian unexplained variance in contrast $1-5$ adalah buruk (>15\%), cukup (10-15\%), baik (5-10\%), sangat baik $(3-5 \%)$, istimewa $(<3 \%){ }^{14}$

Berdasarkan tabel 3 di atas terlihat bahwa nilai variance in data explained by measure tergolong dalam kriteria baik $(44,2 \%)$ yang menunjukkan bahwa butir-butir pernyataan dalam kuesioner mempunyai satu dimensi pengukuran yaitu menjadi alat ukur determinan kepatuhan minum obat. Nilai unexplained variance in contrast 1 sampai 5 seluruhnya di bawah 15\%, hal ini menunjukkan bahwa tidak ada butir pernyataan yang bermasalah atau tidak sesuai tujuan penelitian.

Tabel 4. Rating Scale

\begin{tabular}{cc}
\hline Kategori & Observed Average \\
\hline 1 & -0.89 \\
2 & -0.44 \\
3 & 1.17 \\
4 & 2.09 \\
\hline
\end{tabular}

Uji validitas yang juga dianalisis menggunakan pemodelan Rasch dalam kuesioner determinan kepatuhan minum obat ini adalah rating scale. Rating scale ditentukan berdasarkan nilai observed average, yaitu harus meningkat secara sistematis, dari negatif menjadi positif. Nilai observed average pada tabel 4 di atas memperlihatkan nilai-nilai yang meningkat secara sistematis, hal ini menunjukkan bahwa 4 macam pilihan jawaban (rating) yang disediakan dalam kuesioner mampu dipahami perbedaannya oleh responden.

Uji reliabilitas instrumen menggunakan pemodelan Rasch dilakukan terhadap butir pernyataan (item reliability) dan responden (person reliability) dengan kriteria sebagai berikut: 
lemah(<0,67 logit), cukup (0,67-0,80 logit), baik (0,8-0,90 logit), sangat baik (0,91-0,94 logit), istimewa $(>0,94$ logit $){ }^{14}$

Tabel 5. Reliabilitas Butir Instrumen dan Responden

\begin{tabular}{lcccc}
\hline & Rata-rata Logit & Reliabilitas & Separasi & Alfa Cronbach \\
\hline Instrumen & $+0,00$ & 0,94 & 3,89 & \multirow{2}{*}{0,88} \\
Responden & $+1,01$ & 0,84 & 2,32 & \\
\hline
\end{tabular}

Berdasarkan tabel 5 di atas, nilai reliabilitas butir instrumen $(0,94)$ termasuk kategori sangat baik, sedangkan nilai reliabilitas responden $(0,84)$ termasuk kategori baik. Hasil analisis kedua reliabilitas tersebut menunjukkan bahwa instrumen determinan kepatuhan minum obat pada pasien LES ini memiliki keandalan sebagai alat ukur pada tingkat kesulitan butir pernyataan yang berbeda serta kemampuan responden yang bervariasi.

Nilai separasi strata butir pernyataan dan responden juga diukur dalam uji reliabilitas menggunakan pemodelan Rasch yang dihitung dengan menggunakan rumus berikut: ${ }^{14}$

$$
\mathrm{H}=\frac{[(4 \times \text { SEPARATION })+1]}{3}
$$

Kriteria kualitas butir instrumen dan responden dalam nilai separasi strata adalah: kurang $(<2)$, cukup (2-3), baik (3-4), sangat baik (4-5), istimewa (>5). Kualitas instrumen semakin baik jika memiliki nilai separasi strata tinggi, hal ini menunjukkan bahwa instrumen dapat mengidentifikasi seluruh kelompok responden dan kelompok butir yang ada atau memiliki jangkauan luas sebagai alat ukur. ${ }^{14}$

Berdasarkan tabel 5 di atas, nilai separasi instrumen adalah 3,89, maka hasil perhitungan separasi strata instrumen yaitu 5,5 yang dibulatkan menjadi 5. Hasil separasi instrumen 5 mengandung makna bahwa terdapat 5 kelompok butir pernyataan yang tergolong sangat sulit, sulit, sedang, mudah dan sangat mudah.

Nilai separasi responden pada tabel 5 adalah 2,32, maka hasil perhitungan separasi strata responden yaitu 3,4 yang dibulatkan menjadi 3. Separasi strata responden 3 berarti bahwa terdapat tiga kategori kelompok jawaban responden yang menunjukkan perbedaan tingkat kemampuan responden.

Hasil perhitungan separasi strata di atas termasuk dalam kategori reliabilitas sangat baik pada separasi strata butir dan kategori baik pada separasi strata responden yang berarti instrumen memiliki jangkauan cukup luas pada variasi kesulitan butir pernyataan dan kemampuan responden.

Nilai Alpha Cronbach bertujuan untuk mengukur konsistensi interaksi antara responden dan butir pernyataan secara keseluruhan dengan kriteria sebagai berikut: buruk $(<0,5)$, kurang $(0,5$ $0,6)$, cukup $(0,6-0,7)$, baik $(0,7-0,8)$, dan sangat baik $(>0,8) .{ }^{14}$ Pada tabel 5, nilai Alpha Cronbach adalah $(0,88)$ yang tergolong dalam kriteria sangat baik, sehingga dapat dikatakan bahwa instrumen memiliki konsistensi pengukuran pada responden yang berbeda. Hasil analisis reliabilitas di atas menunjukkan bahwa data aktual yang diperoleh dalam penelitian ini sesuai dengan persyaratan reliabilitas pemodelan Rasch. 
Uji validitas dan reliabilitas di atas menunjukkan bahwa terdapat 20 butir pernyataan yang tidak valid dari 103 butir yang ada, sedangkan uji reliabilitas seudah memenuhi kriteria. Maka dihasilkan instrumen determinan kepatuhan minum obat pada pasien LES yang valid dan reliabel, terdiri dari 51 konstruk yang mewakili 13 kategori seperti terlihat pada tabel 6 dibawah ini.

Tabel 6. Konstruk Valid dan Reliabel Instrumen Determinan Kepatuhan Minum Obat Pada Pasien LES

\begin{aligned} & \hline \multicolumn{1}{c}{ No } Konstruk \\ & \hline 1. Karakteristik Individu \\ & \hline 1 Optimisme \\ & 2 Bersyukur \\ & 3 Mandiri \\ & 4 Bermanfaat \\ & 5 Keyakinan agama \\ & 6 Supel \\ & 7 Kejujuran \\ & 8 Tanggung jawab \\ & 9 Keingintahuan \\ & 10 Penerimaan \\ & 11 Pemaknaan penyakit \\ & 12 Self compare \\ & 13 Self esteem \\ & 14 Relieved \\ & 15 Kontrol diri \\ & 16 Konsistensi \\ & 17 Prioritizing \\ & \hline 2. Daya ingat \\ & \hline 18 Daya ingat \\ & \hline 3. Pengetahuan \\ & \hline 19 Pengetahuan penyakit \\ & \hline 4. Eksperimen \\ & \hline 20 Eksperimen \\ & \hline 5. Manajemen konsumsi \\ & \hline 21 Reminder \\ & 22 Persediaan obat \\ & \hline 23 Karakteristik penyakit \\ & 24 Aktifitas penyakit \\ & 25 Penyakit lain \\ & \hline\end{aligned}




\begin{tabular}{|c|c|}
\hline \multicolumn{2}{|c|}{ 7. Karakteristik Obat } \\
\hline 27 & Efek samping \\
\hline 28 & Jumlah obat \\
\hline 29 & Sifat fisik obat \\
\hline 30 & Tindakan terapi \\
\hline 31 & Dosis \\
\hline 32 & Kualitas obat \\
\hline \multicolumn{2}{|c|}{ 8. Biaya } \\
\hline 33 & Biaya \\
\hline 34 & Jaminan biaya \\
\hline \multicolumn{2}{|c|}{ 9. Kebijakan RS } \\
\hline 35 & Ketersediaan obat \\
\hline 36 & Sarana prasarana \\
\hline 37 & Sistem rujukan \\
\hline 38 & Kompetensi dokter \\
\hline \multicolumn{2}{|c|}{ 10. Akses Fasyankes } \\
\hline 39 & Transportasi \\
\hline \multicolumn{2}{|c|}{ 11. Enabler Agent } \\
\hline 40 & Active screening \\
\hline 41 & Dispensasi \\
\hline \multicolumn{2}{|c|}{ 12. Karakteristik Nakes } \\
\hline 42 & Informasi medis \\
\hline 43 & Kepedulian \\
\hline 44 & Empati \\
\hline \multicolumn{2}{|c|}{ 13. Dukungan Eksternal } \\
\hline 45 & Dukungan keluarga \\
\hline 46 & Dukungan orangtua \\
\hline 47 & Dukungan pasangan \\
\hline 48 & Dukungan teman \\
\hline 49 & Lingkungan \\
\hline 50 & Dukungan lembaga \\
\hline 51 & Kerelawanan \\
\hline
\end{tabular}




\section{KESIMPULAN}

Hasil penelitian ini berupa instrumen determinan kepatuhan minum obat pada pasien LES yang valid dan reliabel sesuai pemodelan Rasch. Instrumen terdiri dari 83 butir pernyataan yang mewakili 51 konstruk dan 13 kategori sebagai berikut: karakteristik individu, daya ingat, pengetahuan, eksperimen, manajemen konsumsi, karakteristik penyakit, karakteristik obat, biaya, kebijakan rumah sakit, akses ke rumah sakit, enabler agent, karakteristik tenaga kesehatan dan dukungan eksternal.

Berdasarkan penelitian ini dapat disimpulkan telah tersedia instrumen yang dianggap sahih dan andal untuk mengukur determinan kepatuhan minum obat pada pasein LES, namun uji yang dilakukan hanya melibatkan responden pasien LES berdomisili di Kota Bandung dan bersuku Sunda sehingga belum tentu sesuai jika digunakan sebagai instrumen penelitian di daerah lain. Penelitian dapat dilanjutkan dengan penelitian kualitatif untuk menentukan determinan kepatuhan yang paling berpengaruh sehingga dapat berkontribusi pada manajemen konsumsi minum obat khususnya pasien LES. Pengembangan penelitian dapat memberi gambaran pentingnya dukungan keluarga maupun berbagai profesi kesehatan selain motivasi internal yang dimiliki odapus, yang berdampak terhadap penatalaksanaan pasien LES untuk meningkatkan kualitas hidup dan menurunkan angka kematian.

\section{DAFTAR RUJUKAN}

Tutuncu ZN, Kalunian KC. The Definition and clasification of systemic lupus erythematosus. In: Wallace DJ, Hahn BH, editors. Duboi’s lupus erythematosus. 7th ed. Philadelphia. Lippincott William \& Wilkins; 2007:16-19.

de Achaval S, Suarez Almazor ME. Treatment adherence to disease-modifying antirheumatic drugs in patients with rheumatoid arthritis and Systemic Lupus Erythematosus. Int J Clin Rheumtol. 2010 June 1;(3): 313-326.

Kamen DL. Adjunctive and preventive measure. Dalam: Wallace DJ, Hahn BH, editor. Dubois, Lupus Erythematosus and related syndrome. Edisi ke-8. Philadelphia:Elsevier Saunders; 2013. hlm. 633-639.

Bugni MV, Ozaki SS, Okamoto KYK. Factors associated with adherence to treatment in children and adolescents with chronic rheumatic diseases. J Pediatr (Rio J). 2012;88(6):483-8.

Abdul-Sattar AB, Abou El Magd SA.Determinants of medication non-adherence in Egyptian patients with systemic lupus erythematosus: Sharkia Governorate.Rheumatol Int. (abstract) 2015; 35 (6): 1045-51.

Julian LJ, Yoolin E, Yazdany J, Panopalis P, Trupin L, Criswell LA, dkk. Depression, medication adherence and service utilization in Systemic lupus erythematosus. Arthritis Rheum. 2009;62(2): 240-246. .

Feldman CH, Yazdany J, Guan H. Medication nonadherence is associated with increased subsequent acute care utilization among medicaid beneficiaries with Systemic Lupus Erythematosus. Arthritis Care \& Research. Vol. 67, No. 12, December 2015, pp 1712-1721. 
Kang SC, Hwang SJ, Chang YS, Chou CT, Tsai CY. Characteristics of comorbidities and costs among patients who died from Systemic Lupus Erythematosus in Taiwan. Arch Med Sci. 2012; 8(4): 690-696.

Horne R, Weinman J, Barber N, et al. Concordance, adherence and compliance in medicine taking: Report for the National Co-ordinating Centre for NHS Service Delivery and Organisation R \& D (NCCSDO). London. 2005. hlm. 48-53.

Lisseanu MG, Greisinger A, Richardson M, et al. Determinants of treatment adherence in ethnically diverse, economically disadvantaged patients with rheumatic disease. J Rheumatol. 2005 May;32(5)[diunduh 1 februari 2016]:913-9. tersedia dari www.ncbi.nlm.nih.gov. Abstrak.

Gonzalez G, Richardson M, Lisseanu MGP, et al. Treatment adherence in patients with rheumatoid arthritis and systemic lupus erythematosus. Rheumatol. 2008 Jul [diunduh 2 Februari 2017];27(7):883-9. Tersedia dari www.ncbi.nlm.nih.gov. Abstrak

Sheba SH, Djuhaeni H, Setiabudiawan B, Sunjaya DK, Mutyara K, Rinawan F. (Maret 2018). Kepatuhan minum obat pada pasien Lupus Eritematosus Sistemik di RSUP Dr. Hasan Sadikin Bandung. Majalah Kedokteran Bandung, 21-28.

Linacre JM. Sample Size and Item Calibration Stability. Rasch Measurement Transactions1994 [diunduh 16 Mei 2016]; 7:4: 328. Tersedia dari www.researchgate.net.

Sumintono B, Widhiarso W. Aplikasi model Rasch untuk penelitian ilmu-ilmu sosial. Edisi revisi; 2015. Trim Komunikata Publishing House. Cimahi

Ward MM. Socioeconomic and Disability Aspects. Dalam: Wallace DJ, Hahn BH, editor. Dubois, Lupus Erythematosus and related syndrome. Edisi ke-8. Philadelphia:Elsevier Saunders; 2013. hlm. 653-658. 